\title{
Paleosol at the Archean-Proterozoic contact in NW India revisited: Evidence for oxidizing conditions during paleo-weathering?
}

\author{
Manoj K Pandit ${ }^{1, *}$, Helga de Wall ${ }^{2}$ and Narendra K Chauhan ${ }^{3}$ \\ ${ }^{1}$ Department of Geology, University of Rajasthan, Jaipur 302 004, India. \\ ${ }^{2}$ Institut für Geologie, Julius-Maximilians-Universitat Würzburg, Pleicherwall 1, 97070 Würzburg, Germany. \\ ${ }^{3}$ Department of Geology, MLS University, Udaipur 313 001, India. \\ *e-mail: mpandit_jp1@sancharnet.in
}

\begin{abstract}
A number of fine-grained sericite bearing pelitic, schistose lithologies occur along the Archean (Banded Gneiss Complex)-Proterozoic (Aravalli Supergroup) contact (APC) in the Udaipur valley in NW Indian craton. These Al-rich lithologies (subsequently metamorphosed) have been described as 'paleosols', developed over a $3.3 \mathrm{Ga}$ old Archean gneissic basement and are overlain by Paleoproterozoic Aravalli quartzite. The paleosol was developed between 2.5 and 2.1, coincident with the globally recognized Great Oxidation Event (GOE). In previous studies these paleosol sections were interpreted to have developed under reducing environment, however, the finding of a 'ferricrete' zone in the upper part of Tulsi Namla section (east of Udaipur) during the present study (in addition to earlier reported lithologies) has led to an alternative suggestion of oxygen-rich conditions during paleosol development. The Tulsi Namla paleosol section shows all the features characteristic of a complete paleosol section described from other Archean cratons. The paleosol includes sericite schist with kyanite as the prevalent Al-silicate in the lower part of profile while chloritoid and Fe-oxides typify the Fe-rich upper part. Alumina has remained immobile during the weathering process while Fe and Mn show a decrease in the lower part of the section and an abrupt rise in the upper part, in the ferricrete zone. The field and geochemical data indicate that the Tulsi Namla section is an in situ weathering profile and at least the upper part shows evidence of oxidizing conditions.
\end{abstract}

\section{Introduction}

Composition of the Earth's early atmosphere has remained largely speculative on account of lack of knowledge regarding suitable signatures, and the development of unusual sedimentary deposits (such as banded iron formations - BIFs) and detrital uraninite and pyrite (Phillips and Law 1997; Minter 1999; Sheldon 2006). The most direct evidence for inferring ambient atmospheric conditions during the early history of the Earth's crust comes from the paleosols as they are formed at the atmosphere-lithosphere interface. Attempts to infer paleoclimatic conditions are, however, hampered by the fact that old paleosols are either partly or completely eroded away or severely altered during later metamorphic and deformation events.

A number of studies carried out in the last two decades have focused on the Precambrian paleosols (Palmer et al 1989; Retallack 1990; Holland 1992; Ohmoto 1996). These studies have shown that immobile major and trace element abundances and variations in REE relative to parent rocks can be used to discriminate paleosols (Panahi et al 2000; Murakami et al 2001; Sreenivas et al 2001) and to 
infer redox conditions during weathering (Ohmoto 1996). It has been interpreted that oxygen was either absent in the atmosphere until $2.3 \mathrm{Ga}$ (or present in very low abundance) and rose rapidly thereafter (Holland 1994, 1999; Rye and Holland 1998). Holland (1994, 1999) described the change from anoxic to oxic conditions as the Great Oxidation Event (GOE) and postulated that by $2.0 \mathrm{Ga}$, the $p \mathrm{O}_{2}$ was atleast 10 to $15 \%$ of the present atmospheric level (PAL). A contrary view was presented by Ohmoto (1997) who provided evidence for atmospheric $\mathrm{O}_{2}$ levels of at least $50 \%$ PAL during the entire past $4.0 \mathrm{Ga}$. Evidence has been drawn from mass independent fractionation properties of sulfur isotopes to favor the rise in atmospheric $\mathrm{O}_{2}$ between 2.4 and $2 \mathrm{Ga}$ (Farquhar et al 2000). However, there is still an ongoing debate about the existence of the GOE as some workers have questioned such a sudden rise in atmospheric oxygen levels and postulated the development of a fully-oxygenated (and methane-poor) atmosphere. Contrasting models are discussed as Cloud-WalkerKasting-Holland and Dimroth-Kimberley-Ohmoto models, respectively (Ohmoto 1997).

Canadian paleosols associated with the subHuronian unconformities are considered to be among the best preserved ones (Panahi et al 2000). They were formed on a 2.5 Ga old Archean granitic and greenstone basement and were subsequently covered by the sediments of the Paleoproterozoic Huronian Supergroup. The Hekpoort paleosol in South Africa, a regional paleoweathering horizon developed on the lavas within Transvaal Supergroup, remains to be the most cited one so far where five paleosol sections, all containing upper iron-poor sericite zones and lower iron-rich chlorite zones were assumed to have developed just before the GOE (Rye and Holland 2000). However, consequent to the discovery of a ferricrete horizon as the uppermost part of the Hekpoort paleosol sections, this interpretation was revised and a formation during the GOE was inferred (Yang and Holland 2003). A pitfall of interpretation of oxidation conditions on the basis of Fe mobility is the fact that some soil profiles are incomplete due to erosion of the upper parts.

There have been limited paleosol studies in the Precambrian sequences of India, mainly confined to the alumina rich rocks. Sreenivas and Srinivasan (1994) postulated that khondalites, especially of northern parts of the Eastern Ghat Mobile Belt, may represent metamorphosed Precambrian paleosols, whereas some high alumina rocks of the Dharwar craton are seen as the metamorphosed hydrothermal alteration products. Some pyrophyllite-diaspore deposits of the Bundelkhand Complex of central India have also been described as paleosols by Sharma (1979). In the region around Udaipur (NW India) large occurrences of fine-grained sericite schist (quarried as 'pyrophyllite'), locally developed over the Archean granite gneisses (Banded Gneiss Complex), have variably been described as possible paleosols (Roy and Paliwal 1981), products of shearing (Ahmad and Rajamani 1988) or hydrothermal alteration products of gneisses (Chauhan 1970). Banerjee (1996) reported a wide-spread occurrence of pelitic, schistose and highly altered lithounits along the contact between Archean BGC and Aravalli Supergroup and described the veneer of such Al-rich lithologies as paleosols. Major element study by Banerjee (1996) provided the first geochemical information on the fossil paleosol wherein he reported an increase in $\mathrm{Al}, \mathrm{Si}$ and $\mathrm{Ti}$ from bottom to the top of the paleosol section and interpreted reducing environment during formation of the paleosol. This view was further endorsed by Sreenivas et al (2001) on the basis of trace and rare earth element data on three paleosol sections (Tulsi Namla, Madar and Barodiya) at the AravalliBGC contact around Udaipur. They described the paleosols as alumina-rich and iron-deficient ones, and developed under-reducing conditions during the weathering. Reddish brown lateritic beds were reported to underlie and overlie dolomite beds in some paleosol sections where siliciclastic Aravalli rocks are not developed (Banerjee 1996). However, such lithologies from the Debari section (also called as Tulsi Namla section) have not been reported so far (Banerjee 1996; Sreenivas et al 2001). We have revisited the Tulsi Namla section and discovered a ferricrete band from the upper part of the section, in addition to the lithologies reported in earlier studies (Sreenivas et al 2001). Iron is a significant paleoclimate indicator and therefore this 'finding', analogous to the Hekpoort paleosol (Yang and Holland 2003), has necessitated a reinterpretation of the paleo-weathering conditions. This paper describes the paleosol profile at Tulsi Namla and mineralogical-geochemical characteristics in the light of the ferricrete band.

\section{Geological setting}

Geological evolution of the NW Indian craton includes a 3.3 to $2.5 \mathrm{Ga}$ old Archean basement (Gopalan et al 1990; Roy and Kröner 1996; Wiedenbeck et al 1996) over which two Proterozoic supracrustal sequences (Aravalli and Delhi Supergroups) were deposited (figure 1). The Palaeoproterozoic Aravalli Supergroup and Mesoto Neoproterozoic Delhi Supergroup occur as a $>700 \mathrm{~km}$ long NE trending linear belt in the Aravalli Mountain Region. The Archean basement, referred to as the Banded Gneiss Complex 


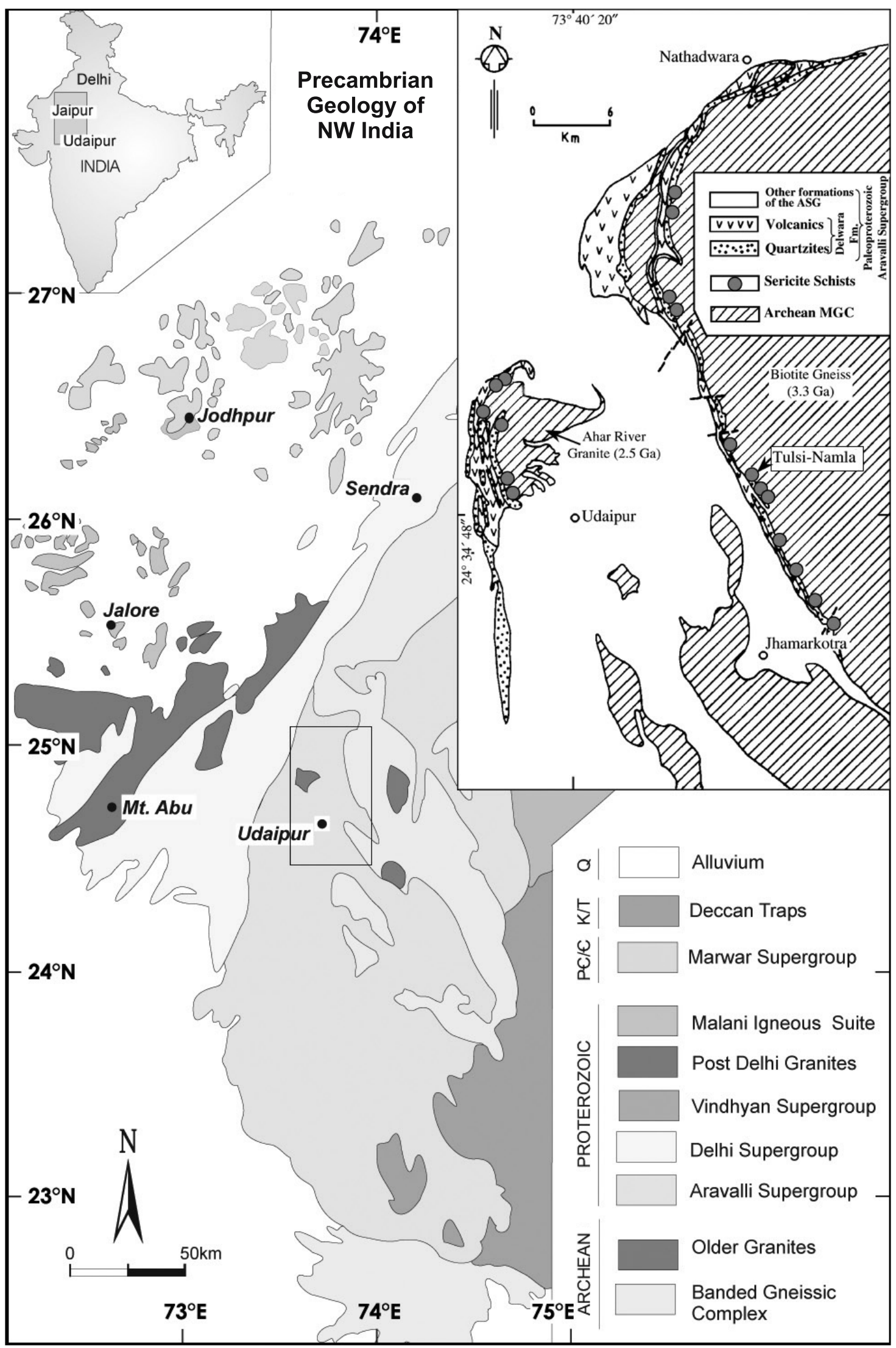

Figure 1. Simplified geological map showing disposition of Precambrian rocks in the NW-Indian craton (adapted from Heron 1953; Gupta et al 1997). The inset map shows the occurrences of sericite schist deposits along the Archean-Proterozoic boundary around Udaipur (Sreenivas et al 2001). The location of Tulsi Namla section (to the east of Udaipur) is also indicated. 
(BGC - Heron 1953) and Bhilwara Supergroup (Gupta et al 1997), consists of biotite gneisses and granites with enclaves of amphibolite, quartzite and marble. In the absence of direct geochronologic data, the $2.1 \mathrm{Ga} \mathrm{Pb}-\mathrm{Pb}$ age of galena (Deb 1999) associated with the basal Aravalli volcanics seems to closely approximate the early sedimentation age of Aravalli Supergroup while the intrusion of $1850 \mathrm{Ma}$ Darwal Granite (whole rock Rb-Sr age - Choudhary et al 1984) has generally been accepted as the minimum age. Both Aravalli and Delhi Supergroups are characterized by multiple deformation episodes (dips varying from 70 to 80 degrees) and polyphase metamorphism. Prominent structural features generally correspond to the prevailing regional NNE tectonic grain. The structure of Aravalli rocks was interpreted to be controlled by NNE to NE trending upright tight folds (Heron 1953). These rocks have recorded three episodes (at places four) of deformation. The Aravalli rocks show low-grade metamorphism in the southern sector and up to amphibolite facies in the north. A general increase in metamorphic grade towards west was also reported by Gupta et al (1997).

The Archean (Banded Gneiss Complex)Proterozoic (Aravalli Supergroup) contact (APC) in the NW Indian craton is punctuated by several occurrences of white mica-rich lithologies. These Al-rich lithologies (subsequently metamorphosed) have been described as 'paleosols', developed over the Archean granitic basement. Banerjee (1996) has identified a number of paleosol sections along a N-S belt and several other localities in Udaipur valley. Sreenivasan et al (2001) described paleosol sections from Madar, Barodiya and Tulsi Namla, from the area around Udaipur. The paleosol section at Tulsi Namla (figure 1) is described in the following section.

\section{Tulsi Namla paleosol section}

The Tulsi-Namla paleosol section is about $12 \mathrm{~m}$ across, with a transitional lower contact with the Archean gneisses and a sharp upper boundary with overlying Aravalli quartzites (figure 2). Banerjee (1996) also found the Tulsi Namla as a complete paleosol section and distinguished a lower quartz-kyanite, white mica-garnet and upper quartz-feldspar, white mica-sericitebiotite-chlorite-calcite assemblages with a gradational contact between the two. The rocks are white to light green in color with some distinct green bands (chrome mica-bearing). Towards the top of the section reddish colors (iron-oxide leaching) prevail indicating the presence of hematite. The whole section represents an overturned structure (described as an inverted limb of a fold) with analogous dips $(065 / 70)$ for schistosity in the sericite rocks and the foliation in overlying Aravalli quartzites. Alternatively, the inversion may be due to a series of listric faults as some of the recent studies have identified reclined to recumbent folds in Aravalli rocks (see Roy and Jakhar 2002). From field observations we have identified various zones in the Tulsi Namla paleosol section at Tulsi Namla, listed below and also shown in figure 2 .

Quartzite (Aravalli Supergroup)

E. Brecciated ferruginous zone with two layers of massive hematite/magnetite (ferricrete zone)

D. Leached zone

C. Nodular (mottled) zone

B. Sericite zone

A. Transition zone (saprolite zone)

Archean Basement (granite gneiss)

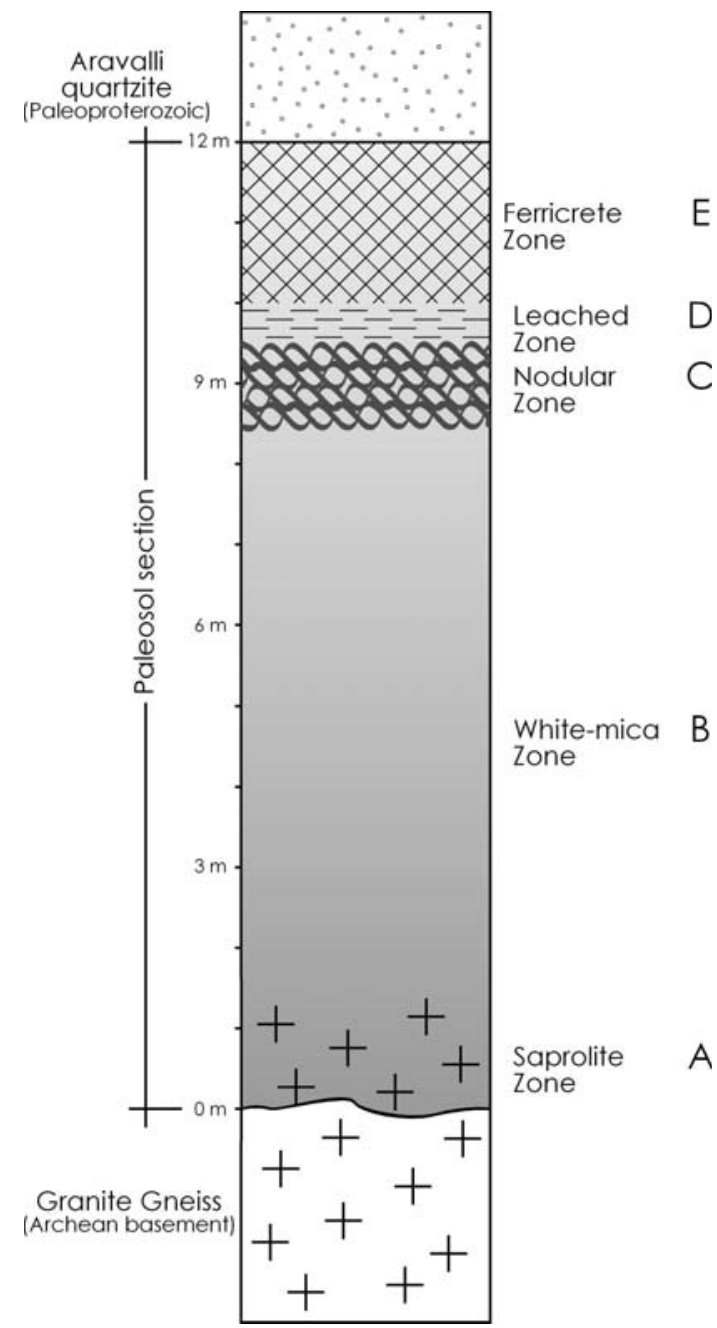

Figure 2. Paleosol section at Tulsi Namla, showing different zones from the granite gneiss (BGC) at the base to Aravalli quartzite at the top. The whole section is part of an overturned structure. 
As shown in figure 2, the basement granite gneisses underlying the sericite schist have alternate felsic and biotite-rich bands. Pristine basement signatures of the protolith are still preserved in zone A, which shows a transitional contact with the basement granite gneiss (Archean). The sericite zone (B) is characterized by a spaced schistosity and development of at least two sets of crenulation lineations. The sericite schist is predominantly off-white in color with a number of green bands of chromium-rich mica. It marks a sharp contact with zone $\mathrm{C}$, the latter characterized by a nodular fabric with $\mathrm{cm}$-size lenses of variable color (white to light red). In the next zone (zone D) which contains large phacoid-shaped relicts of paleosol, a regularly spaced foliation is present. There is an observable predominance of red color towards the top of the sequence into the brecciated hematitic zone (zone $\mathrm{E}$ ), which is also traversed by numerous calcitic vein-lets. Locally, two impersistent ironrich massive bands have been recognized; however, they are not traceable along the entire strike length of the paleosol profile. The sequence of Tulsi Namla paleosol resembles some typical modern weathering profiles.

Spot magnetic susceptibility measurements across the profile have shown very low values in the basement and in the zones $\mathrm{A}$ to $\mathrm{D}$. The values are much higher (in the range of $10^{-3} \mathrm{SI}$ ) in zone $\mathrm{E}$, corresponding to the presence of ferrimagnetic minerals. In the massive bands of the ferruginous zone, the values can reach up to $0.35 \mathrm{SI}$.

\subsection{Petrographic and geochemical characters}

Petrographic characters of different lithologies are illustrated in figure 3 and salient features are also mentioned in the caption. Kyanite is stable in the saprolith and the nodular zone where it forms long prismatic and locally radiating aggregates. The nodular occurrence might be a result of clay (kaolinite)-rich pockets as relict texture in the weathered granite. Metamorphic conditions have been above the upper stability field of pyrophyllite. The ferricrete zone includes chloritoid, quartz and hematite/magnetite as the main mineral phases. Occurrence of chloritoid instead of kyanite in this uppermost zone of the paleosol section is indicative of enrichment of $\mathrm{Fe}$ and $\mathrm{Al}$ prior to metamorphism. Therefore, this iron-rich band most likely represents the metamorphosed Fe-rich top of the paleosol section, unaffected by the shear overprint and related metasomatism that has affected the middle part of the section. The mineral assemblages in the paleosol section indicate a lowgrade metamorphic overprint in the stability field defined by the pyrophyllite-out reaction and the upper stability of chloritoid. The pressure must have been high enough to form kyanite instead of andalusite. This observation is in general agreement with earlier descriptions by Sreenivas et al (2001).

Kyanite is transformed to mica as retrograde reaction. In the white-mica zone this reaction has been complete and relicts of kyanite are scarce. Evidently this transformation is related to shearing. In the transition zone relicts of kyanite-bearing paleosol occur as several $\mathrm{cm}$ clasts within a micaceous matrix between saprolite and white mica zone. The upper part of the nodular zone seems to be generally unaffected by the shear overprint and there is no evidence of any fabric modification related to shear deformation in the ferricrete zone. Therefore, the transformation of kyanite to mica in the central part of the section has, most likely, resulted in strongly localized strain during the shearing event. This raises the possibility that the pristine geochemical signatures of paleosol formation may still be preserved in the ferricrete zone. Petrographic studies of nodular and laterite zone could not be undertaken because the samples are highly friable and would disintegrate during thin section preparation.

\subsection{Geochemical variations}

Geochemical parameters can be used as paleoclimate indicators and for inferring the weathering conditions. However, most of the elements can be variably mobile during post-depositional and metamorphic events. Alumina is considered to be generally immobile while iron is an excellent climatic indicator. The $\mathrm{Al}_{2} \mathrm{O}_{3}, \mathrm{Fe}_{2} \mathrm{O}_{3}$ and $\mathrm{MnO}$ data (XRF analyses) for representative samples were considered. Assuming that the Tulsi Namla represents an in situ weathering profile developed over the Archaean trondhjemitic gneiss, the data were normalized against the likely protolith composition represented by sample JK-1 (unweathered BGC granite gneiss sample collected from an outcrop east of the Tulsi Namla section). The normalized data have been plotted in figure 4 which allows a view of the geochemical variation from bottom to the top of the profile. Compared to the unaffected basement sample, all the samples from the paleosol section show a constant enrichment in $\mathrm{Al}$, as expected for weathering of a granitic basement. $\mathrm{Al}$ is generally immobile during weathering and subsequent processes. Fe is significantly removed from the lower part of the section and is accumulated in the ferricrete zone towards the upper part of the paleosol section. As expected the Mn variations mimic the trends shown by iron, which is a common feature. 

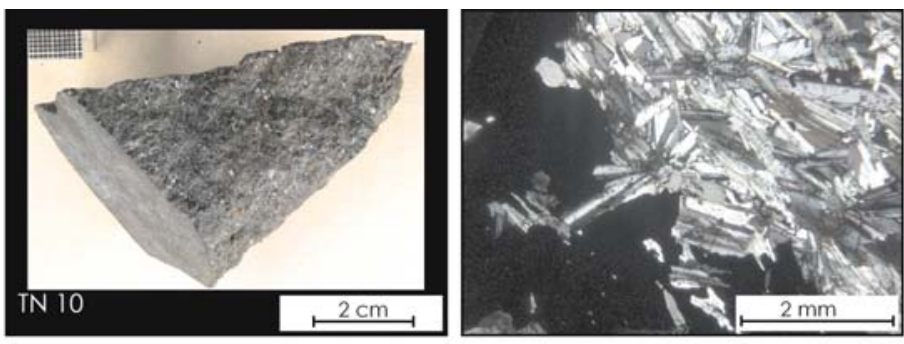

\section{离}
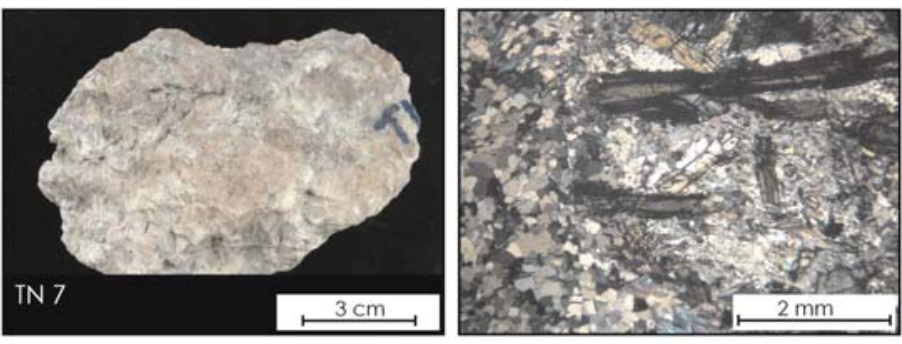

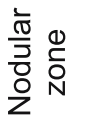
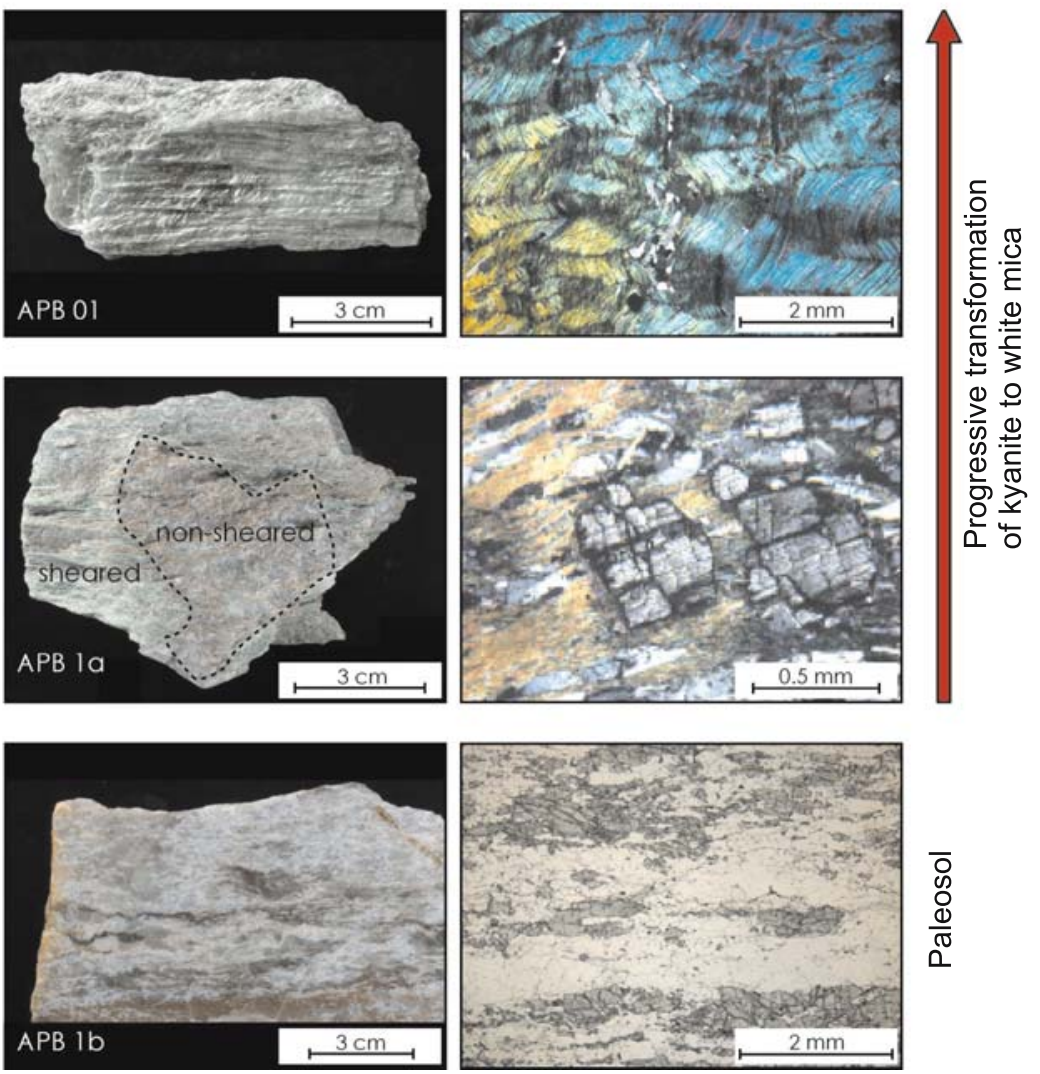

Figure 3. Petrographic characteristics of massive rock units from the Tulsi Namla section. Representative hand specimens (left side) and corresponding thin sections (on the right) are shown. All the photomicrographs are taken under crossed nicols. Thin sections could not be prepared from the leached and brecciated laterite zone due to their highly friable nature. From bottom to top:

a) Protolith of the paleosol is a granite gneiss and in the saprolite zone various grades of overprint by paleo-weathering are seen. In most parts a faint trace of the original gneissic banding is still visible. The prevalant metamorphic mineral in the saprolite and paleosol is kyanite.

b) Transformation of kyanite into white mica due to shearing. Shear deformation is subparallel to the metamorphic banding marked by quartz- and kyanite-rich alternations.

c) Sericite schist is mainly composed of well-foliated white mica with minor quartz bands. The foliation is overprinted by atleast two sets of crenulation cleavages.

d) Irregular fabric with nodular appearance due to cm-size Al-rich mineral aggregates. Log prismatic kyanite crystals showing radiating structure are seen. The nodules are locally rimmed by fine-grained opaque minerals.

e) Massive bands in the ferricrete zone consisting mainly of chloritoid and quartz and large aggregates (several mm) of coarse-grained hematite. Chloritoid laths are randomly oriented and do not show any preferred direction. 


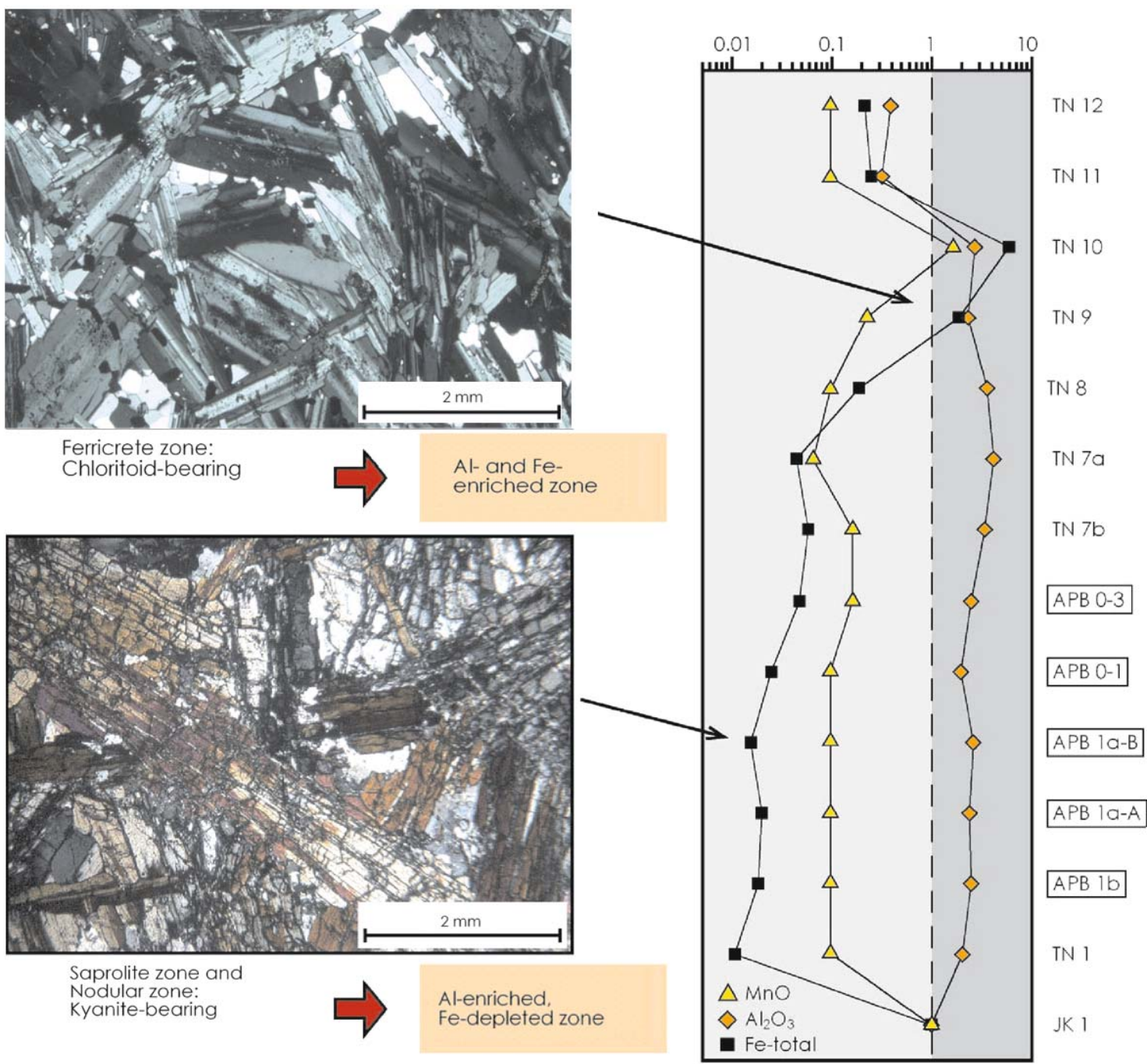

Figure 4. Variation in $\mathrm{Al}, \mathrm{Fe}$ and $\mathrm{Mn}$ abundances relative to the protolith composition (JK - 1) for the Tulsi Namla paleosol profile. Note a constant enrichment level of alumina indicating that Al has remained largely immobile. A sudden rise in $\mathrm{Fe}$ and $\mathrm{Mn}$ enrichment levels in the upper part of the section can be attributed to change in paleoclimatic conditions.

\section{Discussion and conclusion}

The general enrichment of $\mathrm{Al}$ (also indicated by the high volume proportion of kyanite) and formation of a ferricrete zone (here manifested by chloritoid + hematite assemblage) are typical features of lateritic soil profiles. Laterites usually form in warm and humid (tropical) environment under leaching conditions. If the Al-rich Tulsi Namla paleosol is a true laterite, it would imply formation in an oxygenated atmosphere. The paleosol formation indicates a prolonged stable tectonic condition that allowed sustained chemical weathering. There are no direct age constraints for the timing of paleosol formation on top of the Archean basement. An age bracket between 2.5 (cratonization of the Archean basement) and $2.1 \mathrm{Ga}$ (onset of Aravalli sedimentation) can be broadly postulated, which coincides with the interesting time interval of changing atmospheric conditions during the Great Oxidation Event. Banerjee (1996) interpreted prevalence of reducing conditions during formation of the upper part of the paleosol, further supported by Sreenivas et al (2001) who proposed a reducing environment during K-metasomatism and formation of paleosols at the APC under oxygen-deficient conditions. Sreenivas et al (2001) have also reported ${ }^{13} \mathrm{C}$ carbon excursion from lower Aravalli carbonates and correlated it with the globally recognized ${ }^{13} \mathrm{C}$ carbon excursions between 2.22 and $2.06 \mathrm{Ga}$ (see Karhu and Holland 1996). This implies that the atmosphere was already oxygenated during early Aravalli sedimentation (also indicated by widespread stromatolite development in the Aravalli rocks), however, the timing of transition from anoxic to oxic conditions remains speculative.

Paleoclimatic interpretations in earlier studies have not considered the 'iron-rich' band at 
Tulsi Namla section. This seems analogous to the Hekpoort paleosol sections where an oxidizing environment was reinterpreted after the recognition of a ferricrete zone (Yang and Holland 2003). Lithological associations, mineralogical and geochemical characteristics of the Tulsi Namla profile point towards oxidizing conditions during paleosol formation, detailed geochemical and mineral chemical studies are underway to substantiate the interpretation that the APC paleosol in NW India was developed in an oxygen-rich atmosphere. It needs to be ascertained whether the hematite formation was associated with paleosol development or represents a later oxidation event.

\section{Acknowledgements}

This research was initiated during a DAAD (Germany) supported excursion through NW India. The manuscript has benefited by useful reviews and comments by two anonymous reviewers on an earlier version. Special thanks to Franz Fürsich (Würzburg) and Dhirendra Pandey (Jaipur) for conceptualizing and organizing the NW Indian field excursion. Partial financial support was provided by the DFG, Germany (code 446 IND 111/7/05). Luca Nano (Würzburg) is thanked for help in graphics.

\section{References}

Ahmad T and Rajamani V 1988 Geochemistry and petrogenesis of mafic intrusions within the Banded Gneissic Complex near Nathdwara: Implications to BGC-Aravalli relationship; In: Precambrian of Aravalli Mountain, Rajasthan, India, A B Roy (ed.) Geol. Soc. India Memoir 7 327-340.

Banerjee D M 1996 A Lower Proterozoic paleosol at BGCAravalli boundary in south-central Rajasthan, India; J. Geol. Soc. 48 277-288.

Chauhan D S 1970 Pyrophyllite deposit of Barara village, Udaipur district, Rajasthan; Bull. Indian Geol. Assoc. 3 9-12.

Choudhary A K, Gopalan K and Sastry C A 1984 Present status of the geochronology of Precambrian rocks of Rajasthan; Tectonophys. 105 131-140.

Deb M 1999 Metallic mineral deposits of Rajasthan; In: Proc. Sem. on Geology of Rajasthan Status and Perspective (ed.) P Kataria (Geology Dept. MLSU, Udaipur, India) 213-237.

Farquhar J, Bao H and Thiemens M 2000 Atmospheric influence of Earth's earliest sulfur cycle; Science 289 756-758.

Gopalan K, Macdougall J D, Roy A B and Murali A V 1990 Sm-Nd evidence for $3.3 \mathrm{Ga}$ old rocks in Rajasthan, northwestern India; Precamb. Res. 48 287-297.

Gupta S N, Arora Y K, Mathur R K. Iqballuddin, Prasad B, Sahai T N and Sharma S B 1997 The Precambrian Geology of the Aravalli Region, Southern Rajasthan and Northeastern Gujarat; Geol. Surv. India Memoir 123 262 p.
Heron A M 1953 Geology of Central Rajputana; Geol. Surv. India Memoir $\mathbf{7 9}$ 339p.

Holland H D 1992 Distribution and paleoenvironment interpretation of Proterozoic paleosols; In: The Proterozoic Biosphere, (eds) Schopf J W and Klein C (Cambridge Univ. Press) 153-155.

Holland H D 1994 Early Proterozoic atmospheric change; In: Early Life on Earth, Noble Symposium, (ed.) S Bengston (New York: Columbia Univ. Press) 237-244.

Holland H D 1999 When did the Earth's atmosphere become oxic? A Reply; Geochem. News 100 20-22.

Karhu J A and Holland H D 1996 Carbon isotopes and the rise of atmospheric oxygen; Geology 24 867-870.

Minter W E L 1999 Irrefutable detrital origin of the Witwatersrand gold and evidence of eolian signatures; Econ. Geol. 94 665-670.

Murakami T, Utsunomiya S, Imazu Y and Prasad N 2001 Direct evidence of late Archean to early Proterozoic anoxic atmosphere from a product of $2.5 \mathrm{Ga}$ old weathering; Earth Planet. Sci. Lett. 184 523-528.

Ohmoto H 1996 Evidence in pre-2.2 Ga paleosols for the early evolution of atmospheric oxygen and terrestrial biota; Geology 24 1135-1138.

Ohmoto H 1997 When did the Earth atmosphere become oxic?; Geochem. News 93 12-13.

Palmer J A, Phillips G N and McCarthy T S 1989 Paleosols and their relevance to Precambrian atmospheric composition; J. Geol. 97 77-92.

Panahi A, Young G M and Rainbird R H 2000 Behavior of major and trace elements (including REE) during Paleoproterozoic pedogenesis and diagenetic alteration of an Archean granite near Ville Marie, Quebec, Canada; Geochem. Cosmochim. Acta 64 2199-2220.

Phillips G N and Law D M 1997 Hydrothermal origin for Witwatersrand gold; Soc. Econ. Geol. Newslett. 31 26-33.

Retallack G J 1990 Soils of the past - An introduction to paleopedology; (Boston: Unwin and Heyman Inc) 520 p.

Roy A B and Jakhar S R 2002 Geology of Rajasthan (Northwest India) - Precambrian to Recent; Scientific Publishers (India), Jodhpur, 421p.

Roy A B and Kröner A 1996 Single zircon evaporation ages constraining growth of the Aravalli craton, northwestern Indian shield; Geol. Mag. 133 333-342.

Roy A B and Paliwal B S 1981 Evolution of lower Proterozoic epicontinental deposits: Stromatolite-bearing Aravalli rocks of Udaipur, Rajasthan, India; Precamb. Res. 14 49-74.

Rye R and Holland H D 1998 Paleosols and the evolution of atmospheric oxygen; Am. J. Sci. 298 621-675.

Rye R and Holland H D 2000 Geology and geochemistry of paleosols developed on the Hekpoort basalt, Pretoria Group, South Africa; Am. J. Sci. 300 85-141.

Sheldon N D 2006 Precambrian paleosols and atmospheric $\mathrm{CO}_{2}$ levels; Precamb. Res. 147 148-155.

Sharma R P 1979 Origin of pyrophyllite-diaspore deposits of the Bundelkhand Complex, central India; Mineral. Deposita 14 343-352.

Sreenivas B, Roy A B and Srinivasan R 2001 Geochemistry of sericite deposits at the base of the Paleoproterozoic Aravalli supergroup, Rajasthan, India: Evidence for metamorphosed and metasomatised Precambrian Paleosol; Proc. Indian Acad. Sci. (Earth Planet. Sci.) 110 39-61.

Sreenivas B and Srinivasan R 1994 Identification of paleosols in the Precambrian metapelitic assemblages of Peninsular India - A major element geochemical approach; Curr. Sci. 67 89-94. 
Wiedenbeck M, Goswami J N and Roy A B 1996 Stabilization of the Aravalli craton (northwestern India) at $2.5 \mathrm{Ga}$ : Evidence from Ion Microprobe zircon ages; Chem. Geol. 129 325-340.
Yang W and Holland H D 2003 The Hekpoort paleosol in strata 1 at Garborone, Botswana: soil formation during the Great Oxidation Event; Am. J. Sci. 303 $187-220$.

MS received 6 September 2007; revised 27 December 2007; accepted 4 March 2008 